\title{
Atypical presentation of false asystole detection in implantable loop recorder
}

\author{
Simon Andreas Müggler, Jan Steffel, Ardan Muammer Saguner
}

Department of Cardiology, University Heart Centre, University Hospital Zurich, Zurich, Switzerland

\section{Correspondence to} Dr Simon Andreas Müggler, simon.mueggler@gmx.net

Accepted 21 June 2017

\section{(D) crossark}

To cite: Müggler SA Steffel J, Saguner AM. BMJ Case Rep Published Online First: [please include Day Month Year]. doi:10.1136/ bcr-2017-221280

\section{DESCRIPTION}

A 57-year-old male patient was admitted for evaluation of pacemaker explantation 7 years after implantation because of paroxysmal complete atrioventricular (AV) block due to presumed lyme carditis. In view of a stable ventricular pacing rate of $<1 \%$, complete removal of the system without reimplantation was considered. An electrophysiological study revealed normal AV conduction and normal AVBCL (atrioventricular block cycle length). Therefore, pacemaker removal and lead extraction were scheduled, the pacemaker was set to a VVI $30 /$ min mode and a newer generation implantable loop recorder (ILR, Medtronic Reveal LINQ, Medtronic, Dublin, Ireland) was implanted for remote monitoring of the patient's heart rhythm. At a regular outpatient visit 2 weeks later, the ILR indicated an episode of asystole over $7.8 \mathrm{~s}$ (figure 1) during the daytime 1 day after ILR implantation. The patient did not report any symptoms at that time. Pacemaker interrogation showed appropriate function. The episode was hence considered erroneous asystole detection, as described in other case reports. ${ }^{1-3}$ There are several features that point to this conclusion: (1) the blunt deflection at the end of asystole detection is indicative of a non-physiological signal; (2) in a

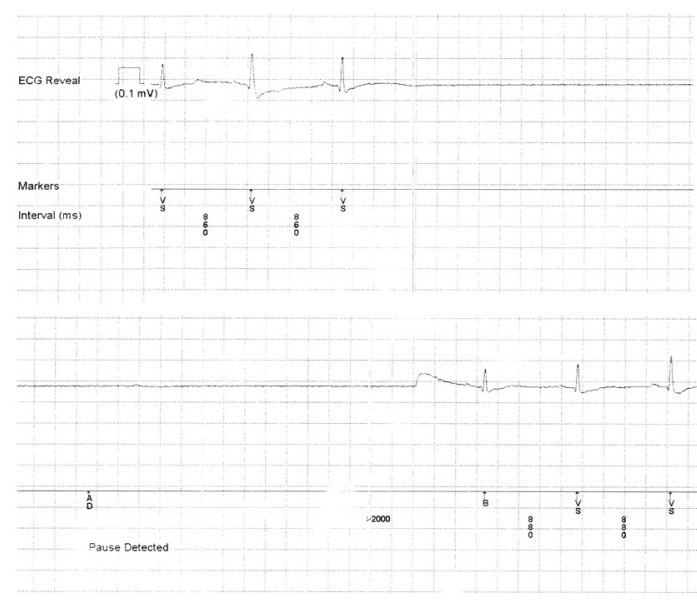

Figure 1 Implantable loop recorder ECG tracing with false asystole detection. patient with a functioning pacemaker programmed at VVI 30/min, an interruption of intrinsic rhythm of $>2000 \mathrm{~ms}$ would result in ventricular stimulation, and spikes $(+/-$ a local depolarisation artefact) should be visible during 'asystole'; (3) the sinus rate interval $(880 \mathrm{~ms})$ does not change significantly after 'asystole', which would be expected in case of true asystole and finally, (4) a complete lack of symptoms was reported by the patient during this episode.

\section{Learning points}

- False asystole detection may occasionally be seen shortly after implantable loop recorder implantation and may have important clinical implications if not diagnosed as such.

- It is suggested due to transitory signal loss because of imperfect device contact with the subcutaneous tissue caused by air entrapment, haematoma or a loose pocket.

- Features indicative of false asystole detection are a blunt deflection at the end of asystole detection (non-physiological signal), lack of symptoms and the sinus rate interval would be expected to change significantly after true asystole.

Contributors SAM wrote the initial manuscript. JS and AMS edited the manuscript. All authors were responsible for the patient's care. All authors read and approved the final manuscript.

Competing interests None declared.

Patient consent Obtained.

Provenance and peer review Not commissioned; externally peer reviewed.

(C) BMJ Publishing Group Ltd (unless otherwise stated in the text of the article) 2017. All rights reserved. No commercial use is permitted unless otherwise expressly granted.

\section{REFERENCES}

1 Bortnik M, Occhetta E, Magnani A, et al. Inappropriate asystole detection in early postoperative phase after loop recorder implantation. ISRN Cardiol 2011;2011:1-3.

2 Ali H, Sorgente A, Daleffe E, et al. Asystole detected by implantable loop recorders: true or false? Ann Noninvasive Electrocardiol 2014;19:595-7.

3 Brenner R, Chenevard R, Ammann P. Is a pacemaker implantation warranted in this patient? Europace 2016;18:245. 
Copyright 2017 BMJ Publishing Group. All rights reserved. For permission to reuse any of this content visit http://group.bmj.com/group/rights-licensing/permissions.

BMJ Case Report Fellows may re-use this article for personal use and teaching without any further permission.

Become a Fellow of BMJ Case Reports today and you can:

- Submit as many cases as you like

- Enjoy fast sympathetic peer review and rapid publication of accepted articles

Access all the published articles

- Re-use any of the published material for personal use and teaching without further permission

For information on Institutional Fellowships contact consortiasales@bmjgroup.com

Visit casereports.bmj.com for more articles like this and to become a Fellow 